Western Washington University Western CEDAR

Woodring College of Education Faculty

Publications

Woodring College of Education

2011

\title{
Multicultural Education as a Human Right: Framing Multicultural Education for Citizenship in a Global Age
}

Francisco Rios

Western Washington University, francisco.rios@wwu.edu

Susan Markus

Follow this and additional works at: https://cedar.wwu.edu/education_facpubs

Part of the Bilingual, Multilingual, and Multicultural Education Commons

\section{Recommended Citation}

Rios, Francisco and Markus, Susan, "Multicultural Education as a Human Right: Framing Multicultural Education for Citizenship in a Global Age" (2011). Woodring College of Education Faculty Publications. 11.

https://cedar.wwu.edu/education_facpubs/11 


\title{
Multicultural Education as a Human Right: Framing Multicultural Education for Citizenship in a Global Age
}

\author{
Francisco Rios \\ Western Washington University \\ Susan Markus \\ University of Wyoming
}

\begin{abstract}
This paper explores the various ways scholars in the field have framed the need for multicultural education. These include changing demographics and closing the academic gap, developing cross-cultural competence, confronting colonization and cultural hegemony, and promoting democratic citizenship. This paper asserts the value of framing multicultural education as a human right: the right to learn about oneself, to learn about others, and to learn citizenship skills associated with a deep democracy in a global age.
\end{abstract}

Keywords: Multicultural education, human rights, education rights, epistemological rights

In today's globalised and interconnected world, living together peacefully has become a moral, social and political imperative on which depends, to a great extent, the survival of human kind. No wonder that education, it its widest sense is called upon to play a major role in this world-wide shared task. 
The need to achieve harmony in a world defined by human diversity in all its manifestations-religious, ethnic, racial, linguistic, etc.-is crucial to the very survival of the human species and the global planet. While the world has always had great diversity, the interaction of people from diverse backgrounds is occurring more substantially contemporarily due in part to immigration, displacement or forced relocation, and the global movement of people for commercial, social, and political purposes. Importantly, as people cross borders of difference, they do not leave their cultural orientations-value systems, worldviews, cultural repertoires of practice, etc.-in their home settings. Thus, the need exists to foster a new way of being: a citizen in a global setting marked by the affirmation of difference, the reality of trans-nationalism, and the ideals of global harmony. As Stavenhagen (2008) asserts, people will have to be educated for this new reality and schools must play an essential role.

This paper adds to the clamor of voices describing the role that multicultural education might play in contemporary contexts marked by both globalization and by efforts to affirm those differences within nation-states. Considering multicultural education as construed internationally, these include books (see, for example, Banks, 2009b; Grant \& Portero, 2011), journals (see, for example, the International Journal of Multicultural Education and Multicultural Education Review) as well as international symposia in professional associations such as the National Association for Multicultural Education in the U.S.

The focus on understanding, respecting and affirming diversity within the nation-state has a much longer history and has been the primary focus of multicultural education (also called intercultural education1) in many nations) since its inception. This occurred since all societies are multicultural "in more than one sense, since, in addition to indigenous peoples, there are also national and ethnic minorities, immigrants from different cultures and other groups demanding their 
right to exercise their cultural identity" (Stavenhagen, 2008, pp. 171-2). We believe that most nation-states have come to recognize the immoral practices associated with forced cultural and linguistic assimilation and have sought models of affirmation of difference while simultaneously promoting social unity.

Another contemporary focus is bridging conditions of difference, both international and domestic, via "cosmopolitan citizenship." Cosmopolitanism is understood, in its classic sense, as an appeal to universal humanity, human rights, and/or world citizenship (Todd, 2009). Importantly, there is considerable scholarship pushing the discourse around cosmopolitanism toward more nuanced understandings that account for context and personal subjectivities (see, Kurasawa, 2007; Pinar, 2009; Popkewitz, 2008; Todd, 2009)2).

While some of the focus on multicultural education in international and culturally diverse national contexts focuses on the value and practices of human rights education (Pimental, 2006), the focus of this paper is on access to quality multicultural education as a human right of its own accord. That is, we argue that all students are entitled to an education that is multicultural. In this regard, we believe that conceptions of human rights need to value the potential role of multicultural education. But we also believe that multicultural education can benefit from rooting itself in human rights principles. More specifically, we assert that the common frames used to conceptualize multicultural education offer a deficit-ridden and/or hegemonic world-view that undermines efforts to affirm diversity.

This paper briefly explores the various ways scholars in the field of multicultural education in the U.S. have framed the need for multicultural education ${ }^{3}$ ). These include changing demographics and closing the academic gap, developing cross-cultural competence, and confronting colonization and cultural hegemony. This paper asserts the value of framing multicultural education as a human right of its 
own accord: the right to learn about oneself, to learn about others, and to learn citizenship skills associated with a deep democracy in a global age

We acknowledge the provocative scholarship of Tove SkutnabbKangas' (2000) on language diversity as a human right that inspires our work. It includes the various international declarations on human rights and education rights but especially UNESCO's Declaration on Cultural Diversity (2001). Finally, it includes the contemporary development of a declaration of education rights, a document in process led by Jim Strickland and Peter Bergson4) (n.d.).

\section{FRAMING THE NEED FOR MULTICULTURAL EDUCATION}

As scholars, the conceptual lenses we use to understand and explain phenomena are important. The impetus for this paper was an anecdotal review of articles that appeared in the journal Multicultural Perspectives, the journal of the National Association for Multicultural Education. It was informed by Ruiz's (1986) review of frames used to describe the need for bilingual education.

According to Ruiz (1986), some framed bilingual education as a problem (focusing instead on English-only approaches to language diversity), while some framed bilingual education as an instrument to achieve assimilationist ends (that is, using bilingual education to get students to speak English as quickly as possible). Ruiz, however, argued for seeing bilingual education as a human right whose means and ends rest with the affirmation of language diversity. Bilingual education, when done well, alters the lingua franca of pedagogy and curriculum while shifting what counts as language asset. 


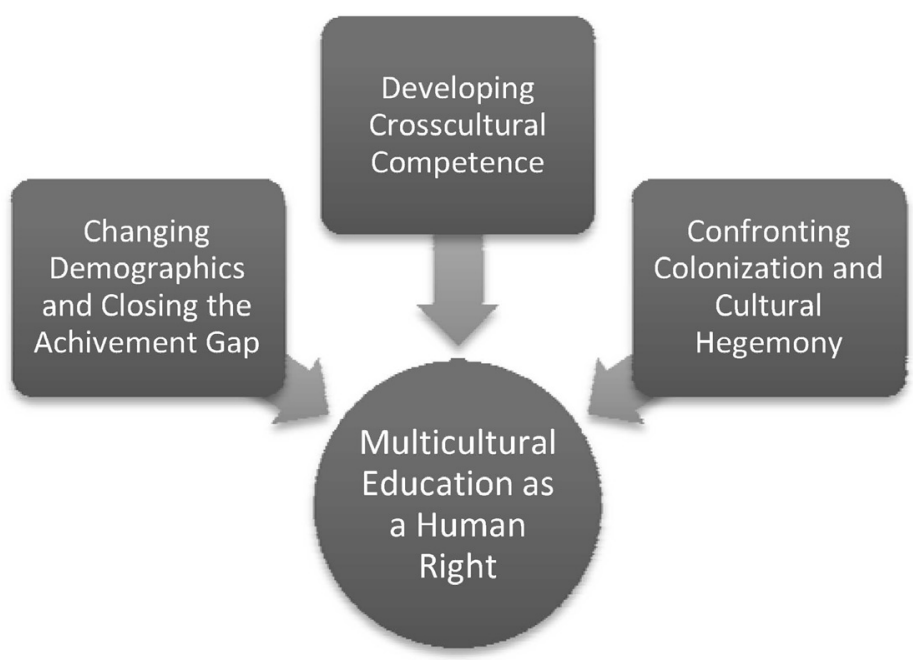

Figure 1. Framing Multicultural Education

Correspondingly, we see the use of arguments around changing demographics and closing the achievement gap as using multicultural education to solve a problem. Developing cross-cultural competence can be seen as an instrument of developing human relations skills and dispositions. Countering colonization and hegemony is aimed at understanding and challenging the ideological and structural underpinnings of social systems (including education). We argue that these frames extend and can be extended by viewing multicultural education as a human right (see Figure 1).

\section{The Frames5)}

\section{Changing demographics and closing the achievement gap}

In our anecdotal review, a common frame for encouraging multi- 
cultural education in the U.S. is to discuss increasing diversity in American classrooms. This frame is often presented with information about achievement gaps between White, middle-class students and students of color, many of whom are living in poverty. These arguments often go on to express that White, middle-class and female persons with little experience with diversity dominate the teaching profession, leading to a mismatch-culturally, linguistically, pedagogically-between students and their teachers.

A second way that scholars frame the need for multicultural education is to close the achievement gap. Just about every measure of academic achievement has been used to document a gap between indigenous, ethnic, linguistic, and immigrant minority students and their White counterparts. While historical arguments suggested non-White students were deprived-culturally, linguistically, socially, etc.-contemporary arguments point to the failure of cultural assimilation models to address the achievement gap. Joel Springs (2009) identified this as "deculturalization" (that is, erasing students' cultural heritage). Multicultural education, on the other hand, is seen as a more productive alternative to schooling than these failed assimilation models.

McCarthy (1988) describes the limits of using such frames since they constitute a racist "non-racism" discourse. It allows the scholar to not discuss racism but rather to use code words like the "the demographic imperative" or "the achievement gap" to implicitly critique those, usually ethnic and/or racial minorities, who are seen as the problem of American education.

\section{Developing cross-cultural competence}

Another frame that scholars in our anecdotal review used to advance multicultural education is to develop cross-cultural competence. 
This typically involves a stage model wherein individuals move from self- awareness, to awareness about diversity, to knowledge of cultural "Others," and finally to skills and dispositions related to cross-cultural competence (for one model applied to multicultural teacher education, see Diller and Moule, 2005). These skills include adapting to students' communication and/or learning style differences as well as making curricular adaptations, assessment modifications, and changes in participation structures within the classroom.

Developing cross-cultural competence as a frame has been critiqued on several accounts. First, it implies some actual end point wherein an individual arrives at enlightenment. Second, these models are often silent about issues of power, racism and/or privilege and the ways they play out in schools. Finally, most models are centered on the movement of Whites towards cross-cultural competency. One notable exception is a typology around how non-Whites might develop cross-cultural competency as conceptualized by Banks (2009a).

\section{Countering a colonizing ideology and cultural hegemony}

Less frequently evidenced in our anecdotal review are frames for multicultural education as countering a colonizing ideology and cultural hegemony. The ideology of colonization includes the proposition that Western Europe is the font of the highest form of civilization (Euro-centrism) and it did so unaided by any other regions/nations of the world (Grant, 2008). It holds in high esteem science, technology, secularism, and individuality. It recognizes that schools are a primary mechanism of inculcation of this ideology and colonization of the mind. Multicultural education becomes a strategy to counter this colonizing ideology and the colonization of the mind. Linda Tuhiwai Smith's (1999) work around decolonization is perhaps 
the most representative in this regard.

Reinforcing colonization is cultural hegemony. It asserts that social groups vie for power. The group in power structures institutions, as well as discourses and ideologies to explain them, to appear natural, neutral, logical and fair. However, these institutional structures (policies and practices) privilege some while oppressing others. These discriminatory policies negatively impact the academic experiences of non-White students.

The primary need for multicultural education is in service of developing a critical consciousness and educational interventions (Freire, 1973, 1985) to combat tacit ideologies, discourses, and institutional structures that privilege the powerful. For Bourdieu (1999), since "there is no genuine democracy without genuine opposing critical powers" (p. 8), resistance is part and parcel of what it means to become educated.

These frames are not mutually exclusive (that is, scholars will use some combination of these frames). For example, the achievement gap might be explained by the lack of cross-cultural competence and/or a hegemonic schooling system. At end, we were disturbed by the prominence of deficit-oriented frames for multicultural education, sought solace in those more progressive frames, and considered extending the frames and rationales for pursuing multicultural education that might be productively employed.

\section{THE FOUNDATIONS OF MULTICULTURAL EDUCATION AS A HUMAN RIGHT}

The proposition that multicultural education is a human right comes from recognition of access to quality education as well as cultural diversity as internationally recognized rights. 


\section{Access to Quality Education as a Human Right}

In initial contemporary international accords, access to education has been understood as an essential human right and a vehicle for advancing human rights6). Article 26 of The United Nations Universal Declaration of Human Rights (1948) described it this way:

Education shall be directed to the full development of the human personality and to the strengthening of respect for human rights and fundamental freedoms. It shall promote understanding, tolerance and friendship among all nations, racial or religious groups, and shall further the activities of the United Nations for the maintenance of peace.

The focus of these efforts was on situating education-free, compulsory, and life-long-as both a mean and end to human rights.

Recently the focus has changed from access toward assuring quality educational experiences (Pimental, 2006). For example, UNESCO's Medium-Term Strategy focused on "improving the quality of education through the diversification of contents and methods..." (Pimental, 2006, p. 11). Threats to quality education, according to Pimental (2006), include increasing neoliberal reforms that consider education an individual good, purchased for commercial interests, as opposed to a public good for community responsibility. The concern is that neoliberalism in education leads to a "two-tiered system that creates inequities rooted in social class, caste, and gender" (p. 8). Other threats to educational quality include gender inequalities, educational exclusion, and school dropout rates.

The focus of education as a human right has primarily been described as an entitlement to the individual. An important shift was evident in 1989, during the United Nations Convention on the Rights of the Child7), where the rights to education for individuals and for 
human rights purposes were affirmed but also extended to include cultural rights. Article 29 states:

States Parties agree that the education of the child shall be directed to:

(a) The development of the child's personality, talents and mental and physical abilities to their fullest potential;

(b) The development of respect for human rights and fundamental freedoms, and for the principles enshrined in the Charter of the United Nations;

(c) The development of respect for the child's parents, his or her own cultural identity, language and values, for the national values of the country in which the child is living, the country from which he or she may originate, and for civilizations different from his or her own;

(d) The preparation of the child for responsible life in a free society, in the spirit of understanding, peace, tolerance, equality of sexes, and friendship among all peoples, ethnic, national and religious groups and persons of indigenous origin;

(e) The development of respect for the natural environment ${ }^{8)}$.

Several things are evident in Article 29. One is consideration of education as central to the development of the fullest human potential. This contrasts with neoliberal efforts to limit the scope of education to the development of people as "workers" (Strickland \& Bergson, n.d.). Second, the role of education to support human rights purposes was once again re-affirmed. Third, the role of education to promote cross-cultural competencies associated with respecting differences and promoting human relations across those differences is made manifest. Finally, Article 29 speaks to the affirmation and respect for one's cultural rights as well as the values of both the current and the heritage nations to which a child identifies. Article 30 of that same 
Convention on the Rights of the Child (1989) went on to state:

In those States in which ethnic, religious or linguistic minorities or persons of indigenous origin exist, a child belonging to such a minority or who is indigenous shall not be denied the right, in community with other members of his or her group, to enjoy his or her own culture, to profess and practise his or her own religion, or to use his or her own language.

Cultural and linguistic diversity was now coupled with human (individual) rights to education.

\section{Cultural Diversity: Expanding the Human Rights Discourse}

Most nation-states now understand the need to assure both individual rights and the collective rights of ethnic and national minorities, language groups, religious minorities, indigenous peoples and migrant communities (Koenig \& de Guchteneire, 2007). This shift to understanding these collective rights has been spurred by globalization and the significant transnational movement of people. It is made more significant as these groups demand full inclusion into the society and recognition for their identities in the public sphere.

At the heart of this demand is a critique of the assumption that cultural homogeneity is required for civic unity. The previous ideology and discourse focused on the rights of the individual and the forging of a culturally uniform national identity. This led to many national policies and programs directed at achieving cultural homogenization, such as the Americanization efforts in the U.S. Claims for ethnic or national recognition were described as threats to national unity.

Challenging the claim of culture homogeneity as a requirement for national unity raises important questions: how can the recognition of group identity also assure trust and solidarity to the nation-state; 
and, how can we reconcile group identity with individual rights for inclusion (Koenig \& de Guchteneire, 2007)? Where previously the focus was on individual rights and national unity via cultural homogenization, the new focus was on a triangle of individual rights, social group identities, and national unity via cultural diversity within a democratic context. The question then becomes: which public policies and institutional arrangements can be developed to assure harmony within this triangle?

Ample public policies related to the human rights of individuals have been pushed as an international value supported by international organizations. Recently this has been extended to include equality and freedom from discrimination for ethnic and linguistic minorities as well as recent immigrants and the need for states to play both a protective role for these social identity groups. Following up from the 1992 Declaration of the Rights of Persons Belonging to National or Ethnic, Religious and Linguistic Minorities, in 1994, the United Nations clarified:

\begin{abstract}
Although the rights $\cdots$ are individual rights, they depend in turn on the ability of the minority group to maintain its culture, language, or religion. Accordingly, positive measures by States may also be necessary to protect the identity of a minority and the rights of its members to enjoy and develop their culture and language and to practice their religion, in community with the other members of the group. (UN doc CCPR General Comment 23: The rights of minorities, April 1994, paragraph 6.2 )
\end{abstract}

The United Nations stated that the nation-state has a role to play in assuring the rights of people of differing social identity groups and that these rights, and the conditions for such, are respected and advanced (Diez-Madrano, 2007). Indeed, nation-states have adopted a number of public policies to assure these rights including affirmative 
action, anti-discrimination policies, and special minority protections (Koenig \& de Guchteneire, 2007). But it is also true that because the context for diversity in each nation-state is different, because they are dynamic, and because they have different historical trajectories, "accommodating cultural diversity therefore requires finding highly context-sensitive pluralistic policy designs" (Koenig \& de Guchteneire, 2007, p. 14).

Failure to respect cultural and linguistic rights has led to efforts at succession and/or violence in places as diverse as Turkey, Spain, Mexico, and Northern Ireland (Diez-Madrano, 2007). In Diez-Madrano's analysis of these and other nation-states, social group antagonism is strengthened by segregation, by how they are discursively "framed" by others (especially by those in power who dominate the means of communication), by policies based on broad sweeping generalizations about them, and by threats to their security and economic well being. Diez-Madrano suggests the need for "shaping a non-antagonistic discourse" (p. 26) about others and promotion of relations between groups.

The most important document connecting the affirmation of cultural diversity to human rights is UNESCO's Universal Declaration on Cultural Diversity (2001). It begins with the principle that as "a source of exchange, innovation and creativity, cultural diversity is as necessary for humankind as biodiversity is to nature" (UNESCO, 2001). It also is "essential to ensure harmonious interaction among people and groups with plural, varied, and dynamic cultural identities as well as a will to live together" (UNESCO, 2001). It makes a direct link between cultural diversity as itself an essential human right. It states that the defense "of cultural diversity is an ethical imperative, inseparable from respect for human dignity. It implies a commitment to human rights and fundamental freedoms" (UNESCO, 2001). 


\section{Affirming Diversity in Education as a Human Right}

Along with others (for example, Strickland \& Bergson, n.d.) we assert that education needs to make manifest human rights and cultural diversity in all aspects of schooling including policies and practices, curriculum and instruction, organizational structures, educational outcomes, assessment practices, etc. Nowhere was this more clearly expressed than in UNESCO's statement on education for indigenous people. Stavenhagen (2008) summarizes the statement in this way:

UNESCO stresses the need for a linguistically and culturally relevant curriculum in which the history, values, languages, oral traditions, and spirituality of indigenous communities are recognized, respected and promoted. Indigenous communities are now calling for a school curriculum that reflects cultural differences, includes indigenous languages and contemplates the use of alternative teaching methods. (p. 168)

Even something as basic as classroom discipline needs to be considered in light of the affirmation of cultural diversity and human rights based principles. This is evidenced in the extended example provided by Du Preez and Roux (2010) demonstrating how basic human relations values serve as a foundation upon which classroom discipline policies and practices are constructed. We appreciate Du Preez and Roux's (2006) acknowledgement that the meanings of both human rights and local cultural values need to be negotiated via dialogue since it "...would be precarious to accept human rights values as univocal and not subjected to diverse interpretation" (p. 23-24). In this context, then, the broader universal values serve as "...a kind of 'floor', an 'irreducible minimum', a mere threshold, which no way of life may transgress without forfeiting its claim to be considered good or even tolerated. Once a society meets these basic principles, it is 
free to organise its way of life as it considers proper" (Parekh, 1999, pp. 130-131). This is termed minimum universality (Parekh, 1999). These human rights values are understood as both a legal and moral construct. Their extended example on classroom discipline in diverse school settings serves as an indicator of the complexity with which framing the affirmation of diversity in school settings might have to contend.

\section{ASSERTING MULTICULTURAL EDUCATION AS A HUMAN RIGHT}

We value the possible roles multicultural education can play to assure access to quality education, affirm cultural and linguistic diversity, and promote broader human rights aims. We posit that there are several rights that multicultural education addresses when implemented authentically and robustly. We describe these seven rights separately but acknowledge their interconnectedness. For example, Yuval-Davis (1999) points to how people--their identities, social systems, and communities-affect and are affected by their activities as citizens. We also acknowledge that multicultural education is constrained unless public policies also attend to broader issues of social segregation, poverty and homelessness, unemployment or underemployment, etc. 


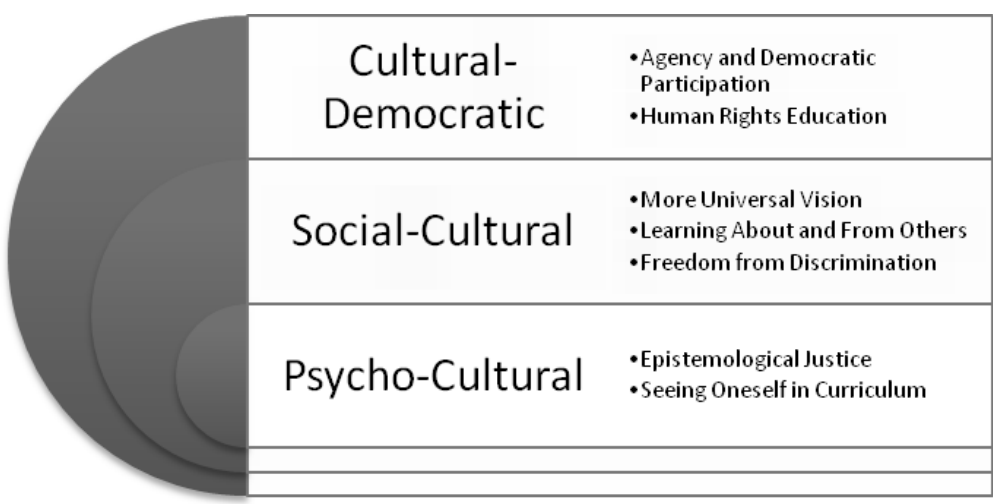

Figure 2. Rights Addressed by Multicultural Education

We suggest that two rights cluster around psycho-cultural rights. These include seeing oneself reflected in the curriculum and epistemological justice. Three rights cluster around socio-cultural rights: Freedom from discrimination, learning about and from others, and having a more universal understanding of reality. The final cluster sets around cultural-democratic rights and include a human rights education and seeing oneself as active agents in democratic development. See Figure 2.

\section{Psycho-Cultural Rights}

\section{Right to see oneself in the curriculum}

Pimental (2006) states that "education is the way through which one can conquer freedom and become a genuine individuated bein g...self-aware and yet deeply and truly connected to others" (p. 3). Likewise, we begin discussion of the human right to a multicultural education with the individual's right to see herself or himself in the curriculum for individual empowerment and as a prerequisite to connecting with others and democratic citizenry. 
Throughout history, a major purpose of education has been to subordinate the individual while promoting the political and economic interests of the State (Pimental, 2006), resulting in the loss of cultural identity among vast majorities of students. However, as Stavenhagen (2008) expresses, "the state model of a culturally homogenised nation does not fit the reality of a multilingual, multiethnic population" ( $p$. 164).

When delivered from a viewpoint that does not integrate all students' cultural worldviews, education has been a tool for destroying indigenous cultures (Stavenhagen, 2008). Sleeter (2008) discusses a similar phenomenon of White Europeans in the U.S. having historically given up their unique cultural identities in order to become American. "Europeans $\cdots$ of diverse ethnic origins created a myth $\cdots$ that emphasized similarity among, and superiority of, people of European descent, set explicitly in contrast to Indians, Mexicans, and Blacks. This myth -.became one of the ways that people of diverse European backgrounds melded, [and] 'forgot' history" (Sleeter, 2008, p. 117).

Banks (2009a) argues that assimilationist ideals results in students' losses of connection with their families, communities, and cultural, linguistic, and ethnic identities, while they are still marginalized in the national civic culture because of their racial characteristics. According to Banks (2009a), teachers and schools in multicultural democratic nations can work together in a process of developing balanced and thoughtful attachments and identifications with their cultural community, their nation, and with the global community in order to become globally competent. According to Banks, "strong, positive, clarified cultural identifications and attachments are a prerequisite to cosmopolitan beliefs, attitudes, and behaviors, and the internalization of human rights values" (p. 39).

Education can play an important role in addressing the losses created by assimilationist policies. It begins with a multicultural and hu- 
man rights-based education in which each student sees her or himself in the curriculum as one tool to address historical educational inequalities. Education must respect and positively represent each student's individual cultural background "so that each person can make the most of it in their personal journey and in their interaction with others $\cdots$.They learn about their past, understand their present, and acknowledge their power to fight for their future" (Pimental, 2006, p.15).

Pedagogical strategies to make it possible for students to be reflected in the curriculum require that teachers learn about their students' cultures and the specific (local) cultural repertoires of practice (Guitterez \& Rogoff, 2003). This requires teachers to make meaningful connections with their students. Pimental (2006) states that, "Teachers become educators when they get fully aware of the surrounding world's influence on every individual. And, most of all, they must be open to the reality of the learners, get acquainted with their ways of being, adhere to their right to be. Educators choose to change the world with learners" (p. 14).

\section{Epistemological justice}

A second multicultural education and human right is learning from the plethora of different ways of knowing and explaining the world, including making sense of the world from the perspectives of one's own cultural worldview. This is the right to epistemological justice.

The dominant epistemology is largely Eurocentric, fueled by Western ideals, which has deleted or significantly distorted knowledge systems of social groups throughout the world and over history. This results in restricted epistemological lenses through which we understand phenomena but also embodies epistemological racism. 
Charlot and Belanger (2003) stated:

Social justice is not possible without cognitive justice, without recognizing the presence of different forms of understanding, knowing and explaining the world. All forms of knowledge have to be present and valued in relation to one another. Faced with the endless map of knowledges, the conclusion is that it is impossible to have a single general theory about the meaning of education and knowledge. Education needs to be a central task of the political system, and political power should help, not only by funding it, but also by having as a priority the fight against the obscuring of non-Western knowledge and local forms of education. (Charlot \& Belanger, 2003; as cited in Chan-Tiberghien, 2004, p. 191).

In keeping with Charlot and Belanger's view, epistemological justice can be viewed through an endless map of knowledges, including border epistemologies (Carter, 2010; Van Houtum, Kramsch, \& Zierhofer, 2005), epistemological diversity (de Sousa Santos, 2007), global competency (Banks, 2009a), spirituality (Tisdell, 2006), and the human right to pursue the good life (Tai, 2010). Embracing ways of knowing that are produced in human communities throughout the world opens up infinite possibilities for global cognitive justice.

As but one example, Tisdell (2006) focuses on the value of alternative forms of epistemology aimed at respecting students' cultural identifications and attachments:

-..by continuing to draw on different modes of knowledge production to inform educational work, including drawing on the cultural imagination through the use of symbol, art, music, and creativity, there is more of a chance for learning to be transformative and culturally responsive because learners are invited to express their culture according to the creative manifestation of their own cultural imagination. (p. 24) 
Banks (2009a) argues that people have a right to access a variety of epistemological orientations and any expanded "learning" repertoires that result. For Gordon (1995), this is not merely about adding more information but reconstituting the conceptual systems that govern models of humanness and modes of being while recognizing and respecting each individual's (culturally-influenced) knowledge system.

As a result of community activism, universities have established academic programs and research centers to acknowledge, document, and extend these differing epistemological systems. They do so both as an end in itself and as a response to colonization and hegemony. As Chan-Tiberghien (2004) related, "Valuing and celebrating diversity- biological, cultural, cognitive, economic, and political-through critical pedagogy, cognitive justice, and decolonizing methodologies becomes a counter-hegemonic alternative" (p. 194).

In short, as Chan-Tiberghien (2004) asserts, "a cosmopolitan model of citizenship requires much more than educators' insurgent acts of critical pedagogy, but a political recognition of cognitive justice/ diversity as well as the availability of previously subjugated knowledges through alternative methodologies" (p. 198).

\section{Social-Cultural Rights}

\section{Freedom from prejudice and discrimination}

Another right shared by multicultural education and international human rights is education free from prejudice and discrimination. This has been a fundamental concern to international human rights organizations. Consider the Convention on the Elimination of Racial Discrimination. The resulting documentation asserts:

States undertake to prohibit and eliminate racial discrimination in all its forms and must adopt effective measures, particularly in the 
fields of teaching, education, culture and information, with a view to combat prejudices which lead to racial discrimination and promote understanding, tolerance and friendship amongst nations and racial or ethnical groups. (in Stavenhagen, 2008, p. 162)

Likewise a central goal of multicultural education has been to combat prejudices and discrimination. A precursor to this effort was scholarship produced, especially in the 1940's and 1950's, to pursue human relations aims. Most notable was Gordon Allport's seminal work The Nature of Prejudice (1954/1979). Allport sought to understand why and how individual level prejudices develop. While the focus on how individuals develop prejudices was significant, it was also limited by its level of analysis at the level of the individual.

Contemporarily multicultural educators recognize other levels at which prejudices operate (Scheurich \& Young, 1997). These include the ways in which institutions structure themselves to privilege some and oppress others. They include the social level by way of the discourses and ideologies of the dominant group shape differences. And they include the philosophical by way of how ontology, axiology, and epistemology are dominated by prejudicial frameworks.

A central tenet of multicultural education is that the reduction of racial and cultural prejudices is not only possible but also desirable (Bennett, 2001). For Sleeter and Grant (2009), while anti-racism is most associated with a human rights approach to education, it is also consonant with all other approaches to multicultural education including social justice approaches. James Banks (2004), in describing five dimensions of multicultural education, posits prejudice reduction as an important aim. Sonia Nieto and Patty Bode (2008), in defining multicultural education, assert anti-racism as a central element. Additionally, Critical Race Theory (CRT) has re-centered racism as a primary explanation for educational inequalities (see Zamudio, 
Russell, Rios, \& Bridgeman, 2011, for a discussion of CRT in schools including the relationship to multicultural education).

Not only has anti-racism and prejudice reduction been centrally located within the discipline of multicultural education but also organizations and educational programs such as the Southern Poverty Law Center's Teaching Tolerance initiative as well as Project RESPECT have emerged in response to addressing this need.

An example of the resurgence of anti-racism work being engaged in and extending multicultural education efforts in schools comes from Vandeyar's (2003) description of debates occurring in postapartheid South Africa: "At the heart of these debates has been the concern that racism still survives in institutional practices across the country. This has led to $\cdots[$ a] shift from multicultural education to anti-racism education $\cdots$ from a preoccupation with cultural difference to an emphasis on the way in which such differences are used to entrench inequality" (p. 196).

\section{Learning 'about' and 'from' others}

We posit that learning about and from others is yet another human right that is supported by multicultural education. According to Stavenhagen (2008), the hope is that in learning about others, we might help students attain "intercultural citizenship [which] takes us beyond cultural diversity to creative interculturality" (p. 162). UNESCO defines interculturality as "the existence and equitable interaction of diverse cultures and the possibility of generating shared cultural expressions through dialogue and mutual respect" (Convention on Cultural Diversity, Article 4.8) (in Stavenhagen, 2008, p. 175). Indeed, John Dewey believed that, "the emphasis must be put upon whatever binds people together in cooperative human pursuits and results $\cdots$.The secondary and provisional character of na- 
tional sovereignty in respect to the fuller, freer, and more fruitful association and intercourse of all human beings with one another must be instilled as a working disposition of mind" (1916, p. 98).

We believe that not only do students have the right to learn about one another in the classroom, but teachers must also participate in this dialogical process with their students. This sharing of learning from one another is a human right as well. Pimental (2006) discusses the engagement of teachers and the community in learning, describing Freire's pedagogical perspective in which all people involved in the process share power over education, rather than subjecting students to the replication of one dominant philosophy: "Teachers and learners share equally the experience of learning through questioning, reflecting, and participating; as a result, this process contributes to the enforcement of infinitely diverse human potentials, instead of refuting, weakening, distorting, or repressing them...the role of the teacher is crucial, $\cdots$ sharing the experience of being in 'quest'" (Pimental, 2006, p. 14).

Unfortunately, as Nieto and Bode (2008) express, "monocultural education is the order of the day in most of our schools. Because viewpoints of so many are left out, monocultural education...deprives all students of the diversity that is part of our world" (pp. 48-49). This deprivation affects all students, including indigenous peoples, students from non-majority cultural backgrounds and White students.

The goal is an ability to interact competently across differences. A right to learn from one another extends beyond the borders of the local community to globally connected learning as well. We agree with Stavenhagen (2008) that, "A truly multicultural society cannot exist simply as a collection of self contained culturally distinct collectivities; these communities must be open to the rest of the world and their members but be free to interact with others" (p. 175). 


\section{Developing a more universal vision of reality}

All of the rights embodied in multicultural education converge to provide students with a more universal understanding of reality. Seeing oneself in one's education, learning from an epistemologically just approach that is free from discrimination, and learning about and relating to others are all necessary in order to provide students with a more universal understanding of reality (revisit Article 29 of the Convention on the Rights of the Child, Section C, described earlier). This human rights document speaks directly to the right of the child to a multicultural education that provides a more universal vision of reality than that which results from a monocultural education. Learning from and about multiple perspectives increases knowledge, enhances insight, and leads to better decision-making for self and others.

Carter (2010) states, however, that "diverse knowledges must not be temporalized or historicized against a Eurocentric timeline of development" (p. 437). Likewise, Agada (1998) advises that "multicultural content $\cdots$ needs to go beyond adding or substituting Afrocentric or Hispanic materials for Eurocentric materials in lesson units. To reflect the notions of relational knowledge, the interdisciplinary curriculum model ought to enable an appreciation of disciplines and subjects as perspectives or lenses for observing reality" (p. 88).

Adichi (2009) cautions against the dangers of a single story, expressing that viewing individuals and their cultures and home countries from one stereotypical story that is told over and over again robs everyone of reality, both the storytellers and the characters in the story. Indeed, in his seminal Talk to Teachers (1963), Baldwin summarized the immense value to all in a curriculum that would not teach a single story, but rather would provide everyone with a more accurate and complete understanding of reality: 
If, for example, one managed to change the curriculum in all the schools so that Negroes learned more about themselves and their real contributions to this culture, you would be liberating not only Negroes, you'd be liberating white people who know nothing about their own history. And the reason is that if you are compelled to lie about one aspect of anybody's history, you must lie about it all. If you have to lie about my real role here, if you have to pretend that I hoed all that cotton just because I loved you, then you have done something to yourself. You are mad.

\section{Cultural-Democratic Rights}

\section{Human rights education}

The role of education to teach about and foster human rights has been evident since the earliest international agreements dedicated to achieving world peace. Recall that the UN Declaration on Human rights in 1948 raised the vital role of human rights education.

Human rights education focuses on teaching students about their human rights and defending themselves from abuse. It includes teaching people about their obligations to others and the importance of being equally diligent about protecting the rights of others. It includes understanding the importance of human agency and how meaningful changes in pursuit of social justice can be carried out peacefully in collaboration with others (Pimental, 2006). Human rights education acknowledges the right to an education but, as Pimental (2006) argued, also aims to promote broader purposes of personal fulfillment, interdependence, and freedom. At end, the ultimate goal of human rights education is empowerment (Pimental, 2006).

UNESCO Bangkok and the UN Special Rapporteur have collaborated to develop A Manual on Rights-Based Education with international human rights law as its foundation (see Pimental, 2006). The 
goal is bringing human rights standards into educational practice. The manual addresses the quality of education, expressing that it should be "learner-centred and relevant to learners, as well as respectful to human rights, such as privacy, gender equality, freedom of expression, and the participation of learners in the education process" (Pimental, 2006, p. 14).

Multicultural education also has a focus on human rights education. Grant and Brueck (2011) see human rights education as one of a broader set of foci within the realm of multicultural education. This includes teaching students, via multicultural education, democratic social participation skills via civic education. The focus of these efforts rests on the core principles of democracy, strategies for extending these principles, and respect for human rights (see, for example, Banks et al., 2005).

Diversity is an important facet of this work around human rights education. Gundara (2000) says, "One of the ways to build bridges of understanding between and among people of various cultures and religions will require an increased appreciation of human rights and the base on which these are built, notably the concept of a shared acceptance of the premise of human dignity. In a period when alienation and cynicism are rife, the role of formal education as utilitarian is not enough" (p. 134). It includes having people understand the interdependent nature of being in this world. In essence, human rights education stresses a relational way of being and shared responsibility as well as an interdependent construal of the self (Tai, 2010).

\section{Knowledge of themselves as active agents and history makers}

Education and teaching are the seeds that will empower the growth of students into active change agents and history makers. Gundara (2000) highlights the role of teachers and education in em- 
powering young people to resist marginalization through developing a voice in society:

Without any concept of value through dignity, the alienation felt by the world's excluded youth will continue to grow $\cdots[$ as] the result of experiencing injustice, marginalization or the lack of a voice, $\cdots$ and teachers can obviously deal with this issue by developing suitable curricula and teaching strategies" (p. 134).

Sleeter and Grant (2009) present and critique various approaches to multicultural education and express that a multicultural social justice approach "goes the furthest toward providing better schooling as well as creating a better society $\cdots$ based largely on social conditions that persist and that limit and often damage or destroy the lives of many people" (p. 229). The multicultural social justice approach engages all people-learners and educators, White heterosexual males and disenfranchised people, privileged and unprivileged-in a concerted, critical effort to analyze the circumstances of their lives and develop social action skills in powerful coalitions that gain strength by working together, across "race, class, and gender lines" (Sleeter \& Grant, 2009, p. 216). By engaging students in this process of social action in schools and communities, students see power in building alliances across difference.

A similar process has been described by Paulo Freire, who "viewed empowering pedagogy as a dialogical process in which the teacher acts as a partner with students, helping them to examine the world critically, using a problem-posing process that begins with their own experience and historical location" (Sleeter \& Grant, 2009, p. 213). Likewise, the Institute for Democratic Education in America (Strickland \& Bergson, n.d.) exists "to ensure that all young people can participate meaningfully in their education and gain the tools to build a just, democratic and sustainable world." 
Zamudio, Bridgeman, Russell and Rios (2009) highlight empowering students to participate meaningfully with their teachers in the quest for equality. These authors express that:

The problems in helping to develop a critical consciousness are overwhelming $\cdots$.But we engage this work in solidarity with others, all those others across the country, and with our students who $\cdots$ are unwilling participants in a hegemonic system that has denied them access to alternative narratives. The costs are high for students and teachers alike. These hegemonic conditions make our state of otherness appear 'natural'. These positions of otherness, however, allow us to access the counterstories that make a critical education possible. It is our own self-assessment of both our position of privilege and otherness that has developed into a critical consciousness. (p. 470-471)

Human rights in education include the right of people to participate in decisions that affect them (Strickland \& Bergson, n.d.). It includes being an active agent to change socially unjust institutional structures, policies and practices "...in an effort to challenge current state policies that discriminate against, or simply ignore people based on their socio-economic status, race, gender, dis/ability, religion or sexual orientation." (Grant, 2008, p. 9).

\section{CONCLUSION}

We argue that contemporary understandings of human rights and education converge in productive ways with contemporary but especially critical multicultural education principles. They both share a belief that cultural diversity is essential for human rights, democracy, and social justice. As articulated by UNESCO's (2002) Convention on Cultural Diversity: "cultural diversity, flourishing within a frame- 
work of democracy, tolerance, social justice and mutual respect between peoples and cultures, is indispensible for peace and security at the local, national and international levels."

The next step is moving these human right principles to actual educational practices. We believe that multicultural education could become THE première pedagogical framework from which this move from principles to practices might occur. This will require teacher training around multicultural education, reducing institutional resistance, changing the ideology and dialogue of ministry and state education officials, and building alliances with teacher associations and unions. Consider descriptions of what this might look like in actual practice as described by Nieto and Bode (2008) as well as the recent publications by $\mathrm{Au}$ (2009) and Quijada Cerecer, Alvarez Gutiérrez, and Rios (2010).

Fortunately, there are important models of what a multicultural and human rights oriented approach to education might entail. At the heart of these are robust, authentic, and deep connections with indigenous, minority, and immigrant communities who are seen as vital actors. These include the Atuarfitsialak program in Greenland, the Alaska Native Knowledge Network, the Maori of New Zealand, and the Student Educational and Cultural Movement of Ladakh (India) (Stavenhagen, p. 169-171).

The goals of such programs must lead to interculturality, enlightened cosmopolitans, intercultural citizenship (Stavenhagen, 2008) and cosmopolitan citizenship (Chan-Tiberghien, 2004). Globalization should be used to facilitate development of such citizenships. Conversely, such programs must also include a critical eye toward critiquing the impact of globalization for narrow neoliberal purposes (Chan-Tiberghien, 2004).

We wish to reiterate that multicultural education is not the only mechanism necessary to achieve human rights. As we have described 
earlier, students move across a range of social institutions and many schools remain sites of exclusion and discrimination. But multicultural education may be an initial (even if partial) entry point to preserving and extending students' educational human rights.

We sought to answer the question, can education that is multicultural be considered a human right? Given the ways in which the two converge, we see tremendous possibility in the ways in which multicultural education advances universal human rights. The convergence of these two, in the words of Fitzsimons (2000), bring together "the conditions of possibility for education [and educators] at the intersection of the discourses of the integrated world order on the one hand, and those of the forces of difference on the other" (p. 515).

\section{Notes}

1) See Portero (2011) for an extended discussion on the origins and uses of these two terms.

2) The discussion of cosmopolitanism is outside the intent of this paper. However, for those interested, see Spector's 2011 review of these books.

3) We acknowledge the limitation of reviewing literature from the US nearly exclusively and invite our international colleagues to explore frames used in other contexts.

4) For more information, contact these authors at: livedemocracy@hotmail.com

5) A more comprehensive discussion of these frames can be found in Rios and Stanton Rogers, 2011.

6) See Pimental, 2006, for a historical overview of the development of education as a human right.

7) 191 of 193 countries have ratified; the USA and Somalia have not (Skutnabb-Kangas, 2000)

8) Environmental justice and ecological literacy as well as environmental sustainability have recently become even more prominent given UNESCO's Decade of Sustainability focus. 
MULTICULTURAL EDUCATION REVIEW

\section{REFERENCES}

Adichi, C. (2009). The danger of a single story [Video cast]. Retrieved from http://www.youtube.com/watch?v=D9Ihs241zeg

Agada, J. (1998). Multicultural education and the emerging paradigm: An essay in cultural epistemology. The Urban Review, 30(1), 77-95.

Allport, G. W. (1954/1979). The nature of prejudice. Cambridge, MA: Perseus Books.

$\mathrm{Au}, \mathrm{W}$. (Ed.). (2009). Rethinking multicultural education. Milwaukee, WI: Rethinking Schools.

Baldwin, J. (1963, December 21). A talk to teachers. Saturday Review, 42-44.

Banks, J. A. (2004). Multicultural education: Historical development, dimensions, and practice. In J. A. Banks, \& C. A. McGee Banks (Eds.), Handbook of research on multicultural education (2nd ed., pp. 2-29). San Francisco: Jossey-Bass.

Banks, J. A. (2009a, May). Diversity and citizenship education in nation's around the world. paper presented at the Korean Educational Association for Multicultural Education, Seoul, South Korea.

Banks, J. A. (2009b). The Routledge international companion to multicultural education. New York: Routledge.

Banks, J. A., McGee Banks, C. A., Cortés, C., Hahn, C. L., Merryfield, M. M., Moodley, K. A., Murphy-Shigematsu, S., Osler, A., Park, C., \& Parker, W. C. (2005). Democracy and diversity. Seattle, WA: Center for Multicultural Education, University of Washington. Available at: http:// depts.washington.edu/centerme/demdiv.htm.

Bennett, C. (2001). Genres of research in multicultural education. Review of Educational Research, 71(2), 171-217.

Bourdieu, P. (1999). Acts of resistance. New York: New Press.

Carter, L. (2010). The armchair at the borders: The "messy" ideas of borders and border epistemologies within multicultural science education scholarship. Science Education, 94(3), 428-447.

Chan-Tiberghien, J. (2004). Toward a 'global educational justice' research paradigm: cognitive justice, decolonizing methodologies and critical pedagogy. Globalisation, Societies and Education, 2(2), 191-213. 
Multicultural Education as a Human Right

Charlot, B., \& Belanger, P. (2003). Education. In W. Fisher \& T. Ponniah (Eds.), Another world is possible: Popular alternatives to globalization at the world social forum (pp. 202-211). London: Zed Books.

de Sousa Santos, B. (Ed.). (2007). Another knowledge is possible: Beyond Northern epistemologies. London: Verso.

de Sousa Santos, B. (2003, March). The world social forum: Toward a counter-hegemonic globalization. Paper presented at the XXIV International Congress of the Latin American Studies Association, Dallas, TX.

Dewey, J. (1916). Democracy and education. New York: Free Press.

Diez-Medrano, J. (2007). Nationalism, ethnic conflict and democratic governance. In M. Koenig \& P. de Guchteneire (Eds.), Democracy and Human Rights in Multicultural Societies (pp. 21-33). Paris, France: UNESCO and Burlington, VT: Ashgate Publishing Co.

Diller, J. V., \& Moule, J. (2005). Cultural competence: A primer for educators. Belmont, CA: Thompson Wadsworth.

Du Preez, P., \& Roux, C. (2010). Human rights values or cultural values? Pursuing values to maintain positive discipline in multicultural schools. South African Journal of Education, 30, 13-26.

Fitzsimons, P. (2000). Changing conceptions of globalization: Changing conceptions of education. Educational Theory, 50(4), 505-521.

Freire, P. (1973). Education for critical consciousness. New York: Seabury Press.

Freire, P. (1985). The politics of education: culture, power and liberation. Hadley, MA: Bergin \& Garvey.

Gordon, B. (1995). Knowledge construction, competing critical theories, and education. In J. A. Banks \& C. A. McGee Banks (Eds.), History of Research on Multicultural Education (pp. 184-199). New York: Macmillian.

Grant, C. A. (2008, January). The evolution of multicultural education in the United States. Paper delivered at the International Association for Intercultural Education, Turin, Italy.

Grant, C. A., \& Brueck, S. (2011). A global invitation: Toward the expansion of dialogue, reflection and creative engagement for intercultural and multicultural education. In C. A. Grant \& A. Portero (Eds.), Intercultural and Multicultural Education (pp. 3-11). New York and London: Routledge.

Grant. C. A., \& Portero, A. (2011). Preface. In C. A. Grant \& A. Portero (Eds.), 
Intercultural and Multicultural Education (pp. xi-xii). New York and London: Routledge.

Gutierrez, C., \& Rogoff, B. (2003). Cultural ways of learning: Individual traits or repertoires of practice. Educational Researcher, 5(32), 19-25.

Gundara, G. (2000). Religion, human rights and intercultural education. Intercultural Education, 11(2), 127-136.

Koenig, M., \& de Guchteneire, P. (2007). Political governance of cultural diversity. In M. Koenig \& P. de Guchteneire (Eds.), Democracy and Human Rights in Multicultural Societies (pp. 3-17). Paris, France: UNESCO and Burlington, VT: Ashgate Publishing Co.

Kurasawa, F. (2007). The work of global justice: Human rights as practices. UK: Cambridge University Press.

McCarthy, C. (1988). Rethinking liberal and radical perspectives on racial inequality in schooling: Making the case for nonsynchrony. Harvard Educational Review, 58(3), 265-279.

Nieto, S., \& Bode, P. (2008). Affirming diversity: The sociopolitical context of multicultural education (5th ed.). Boston: Pearson Education, Inc.

Parekh, B. (1999). Non-ethnocentric universalism. In T. Dunne \& N. J. Wheeler (Eds.), Human rights in global politics (pp. 128-159). Cambridge: Cambridge University Press.

Pimental, X. (2006). The human right to education: Freedom and empowerment. Multicultural Education, 13(4), 2-10.

Pinar, W. (2009). The worldliness of a cosmopolitan education: Passionate lives in public service. New York: Routledge.

Popkewitz, T. (2008). Cosmopolitanism and the age of school reform: Science, education, and the making society by making the child. New York: Routledge.

Portero, A. (2011). Intercultural and multicultural education: Epistemological and semantic aspects. In C. A. Grant \& A. Portero (Eds.), Intercultural and Multicultural Education (pp. 12-32). New York and London: Routledge.

Quijada Cerecer, P., Alvarez Gutiérrez, L., \& Rios, F. (2010). Critical multiculturalism: Transformative educational principles and practices. In $\mathrm{T}$. K. Chapman \& N. Hobbel (Eds.), Social justice pedagogy across the curriculum (pp. 144-163). NY: Routledge.

Rios, F., \& Stanton-Rogers, C. (2011). Understanding multicultural education. 
Multicultural Education as a Human Right

Rowman \& Littlefield.

Ruiz, R. (1984). Orientations in language planning, NABE Journal, 8(2), 15-34.

Skutnabb-Kangas, T. (2000). Linguistic genocide in education, or worldwide diversity and human rights? Mahwah, NJ: Lawrence Erlbaum Associates.

Sleeter, C. E. (2008). Critical family history, identity, and historical memory. Educational Studies 43 (2), 114-124.

Sleeter, C. E., \& Grant, C. A. (2009). Making choices for multicultural education: Five approaches to race, class, and gender (6th ed.). Hoboken, NJ: John Wiley \& Sons, Inc.

Spector, H. (2011). The question of cosmopolitanism: An essay review. Education Review, 13(4). Retrieved March 3, 2011, from http://edrev.info/essays/v14n2.pdf

Spring, J. (2009). Deculturalization and the struggle for equality. New York: McGraw-Hill.

Stavenhagen, R. (2008). Building intercultural citizenship through education: A human rights approach. European Journal of Education, 43(2), 161-179.

Strickland, J., \& Bergson, P. (n.d.). Declaration of education rights: A light in the darkness (unpublished document). Available by contacting: livedemocracy@hotmail.com

Tai, E. (2010). Local and global efforts for human rights education: A case from the Osaka human rights museum. The International Journal of Human Rights, 14(5), 771-788.

Tisdell, E. J. (2006). Spirituality, cultural identity, and epistemology in culturally responsive teaching in higher education. Multicultural Perspectives, 8(3), $19-25$

Todd, S. (2009). Toward an imperfect education: Facing humanity, rethinking cosmopolitanism. Boulder, CO: Paradigm Publishers.

Tuhiwai Smith, L. (1999). Decolonizing methodologies: Research and Indigenous people. London: Zed Books.

United Nations. (1989). United Nations Convention on the Rights of the Child. Retrieved from http://www2.ohchr.org/english/law/crc.htm

United Nations. (1948). The United Nations Universal Declaration of Human Rights. Retrieved from http://www.un.org/en/documents/udhr/

UNESCO. (2002). UNESCO Declaration on Cultural Diversity. Retrieved from 
http:/ / unesdoc.unesco.org/images/0012/001271/127160m.pdf

Vandeyar, S. (2003). The jagged paths to multicultural education: international experiences and South Africa's response in the new dispensation. South African Journal of Education, 23(3), 193-198.

Van Houtum, H., Kramsch, O., \& Zierhofer, W. (Eds.) (2005). B/ordering space. Aldershot, England: Ashgate.

Yuval-Davis, N. (1999). The multi-layered citizen. International Journal of Feminist Politics, 1(1), 119-136.

Zamudio, M., Bridgeman, J., Russell, C., \& Rios, F. (2009). Developing a critical consciousness: Positionality, pedagogy, and problems. Race Ethnicity and Education, 12(4), 455-472.

Zamudio, M., Russell, C., Rios, F., \& Bridgeman, J. (2011). Critical race theory matters: Education and ideology. New York: Routledge/Taylor \& Francis.

Francisco Rios is Dean of the Woodring College of Education at Western Washington University. $\mathrm{He}$ is the Senior Associate Editor of Multicultural Perspectives, the journal of the National Association for Multicultural Education.

E-mail: Francisco.Rios@wwu.edu

Telephone: +1-360-650-3319

Postal Address: Woodring College of Education Miller Hall 250, MNS 9088516 High Street Bellingham, WA 98225

Susan Markus is a Ph.D. student in Educational Leadership at the University of Wyoming. She is the Deputy Director of the Wyoming Health Council in Cheyenne, Wyoming.

E-mail: Smarkus@uwyo.edu

Telephone: +1-307-274-6292

Postal Address: Wyoming Health Council 416 W. 24th St. Cheyenne, WY 820 
